\title{
Passage of infectious pancreatic necrosis virus (IPNV) through invertebrates in an aquatic food chain
}

\author{
Stein H. Mortensen \\ Institute of Marine Research, Department of Aquaculture, Fish Health Division, PO Box 1870, N-5024 Bergen-Nordnes, \\ Norway
}

\begin{abstract}
Infectious pancreatic necrosis virus (IPNV) was reisolated from particles containing faeces and pseudofaeces of scallops Pecten maximus after IPNV bath and injection challenges, and from prawns Pandalus borealis and Palaemon elegans which had grazed upon dead IPNV-contaminated scallops. Virus was also reisolated from prawns which were physically isolated from the scallops, but in contact with IPNV-contaminated scallop faeces and pseudofaeces. Virus titers of the prawns decreased rapidly after the contaminated food source was removed. IPNV was not detected in brown trout Salmo trutta which were fed prawns which contained $10^{2.5}$ to $10^{3.2} \mathrm{TCID}_{50} \mathrm{~g}^{-1}$ wet weight, but was transmitted to 2 of 8 trout which were fed food pellets with a virus titer of $10^{6} \mathrm{TCID}_{50} \mathrm{~g}^{-1}$ wet weight.
\end{abstract}

\section{INTRODUCTION}

Infectious pancreatic necrosis virus (IPNV), or perhaps more precisely an IPNV-like aquatic birnavirus, has been isolated from scallops Pecten maximus (Mortensen et al. 1990) and from mussels Mytilus edulis, located in the vicinity of a salmon farm in Norway (unpubl. results). Invertebrate filter-feeders like bivalve molluscs ingest and accumulate particulate material, including virus particles (Canzonier 1971, Di Girolamo et al. 1977). Virus may persist sequestered in the digestive tissues of molluscs (Canzonier 1971, Hay \& Scotti 1986), and thus potentially be progressively passed on in food chains by classical predator-prey relationships.

Another potential route of transmission is feeding on particulate matter like faeces or pseudofaeces or on deteriorating material. In this way scavengers and detritus feeders may take up, and thus potentially serve as vectors of, agents pathogenic for fish. Different crustaceans like prawn and shrimp species represent important links in marine food chains and constitute a major part of the diet of a variety of fish species. IPNV or an IPNV-like aquatic birnavirus has previously been isolated from prawns Palaemon elegans most likely in- fected by feeding upon deteriorating turbot fry during an infectious pancreatic necrosis epizootic in a commercial farm (unpubl. results). As fish may be infected with pathogenic agents by ingestion of contaminated food, pathogen-containing prey may constitute a link of disease transmission from one trophic level to the next.

The aim of the present work was to study if IPNV could be passed through a marine food chain, including uptake and release of the virus by bivalve molluscs, further transmission to prawns, and from prawns to trout.

\section{MATERIALS AND METHODS}

Animals. Prawns Palaemon elegans were collected with a net in shallow water in an estuary at Tysnes, south of Bergen, Norway. Pandalus borealis were collected from $200 \mathrm{~m}$ depth by trawl in Raunefjorden southwest of Bergen and rapidly transferred to tanks with running seawater. Wounded and passive specimens were sorted out. Prawns of both species were transferred to, and acclimatized in, $250 \mathrm{I}$ aquaria with running filtered seawater at $10^{\circ} \mathrm{C}$. 
Scallops Pecten maximus were received from the Austevoll Marine Research Station and from the Bergen Aquarium, and kept in 250 l aquaria in running filtered seawater at $10^{\circ} \mathrm{C}$. They were not fed during the experimental period. IPNV was not detected in hepatopancreas samples from control scallops prior to the experiments.

Brown trout Salmo trutta, 18 mo old and with an average weight of approximately $30 \mathrm{~g}$, were provided from the Institute's own hatchery-reared stock.

Virus. The virus used was infectious pancreatic necrosis virus (IPNV) isolated from Norwegian scallops Pecten maximus (Mortensen et al. 1990).

Cell culture. The rainbow trout gonad (RTG-2) cell line (Wolf \& Quimby 1962) was used for virus propagation, detection and titration. Cells were cultured at $20{ }^{\circ} \mathrm{C}$ in Earle's modification of minimum essential medium (EMEM) supplemented with $10 \%$ foetal bovine serum, $1 \%$ non-essential amino acids, L-glutamine (200 mM) and Gentamicin solution. As older confluent cell layers of the RTG-2 cell line are known to produce interferon (Okamoto et al. 1983), all plates and flasks were prepared the day before use, at a seeding rate of 2.5 to $3.0 \times 10^{4}$ cells per well (approximately $9 \times 10^{4}$ $\mathrm{cm}^{-2}$ ).

Virus titrations. Virus titrations were performed by end-point dilutions on RTG-2 cell layers in 96 well Nunclon microtiter plates using 12 wells per dilution. Infected cell layers were identified by the cytopathic effect (CPE) $6 \mathrm{~d}$ after inoculation. Virus titers were calculated as $\mathrm{TCID}_{50} \mathrm{ml}^{-1}$ or $\mathrm{TCID}_{50} \mathrm{~g}^{-1}$ tissue according to the method of Reed \& Muench (1938). In a few wells where the CPE was questionable, $50 \mu l$ undiluted culture fluids from the wells were inoculated onto fresh RTG-2 cell layers and incubated for another $6 \mathrm{~d}$.

Virus detection. For virus detection, $0.2 \mu \mathrm{m}$ filtered dilutions (1:50) of tissue suspensions in EMEM cell culture medium were inoculated onto RTG-2 cellcultures in $25 \mathrm{~cm}^{2}$ tissue-culture flasks $(0.5$ to $1.0 \mathrm{ml}$ per flask). If no CPE was observed after $6 \mathrm{~d}, 2$ blind passages were attempted in fresh cell cultures. IPNV in supernatants from flasks with $\mathrm{CPE}$, and reisolated IPNV after challenges, were confirmed by Enzyme Linked Immunosorbent Assay (ELISA) using monoclonal antibodies $\mathrm{H} 8$ and $\mathrm{A} 8$ directed against the $\mathrm{Vp} 2$ and $\mathrm{Vp} 3$ proteins of IPNV respectively (Christie et al. 1990).

Expt 1: Challenge of scallops with IPNV. Group 1: Thirteen scallops were each injected with $1 \mathrm{ml}$ of virus suspension containing $10^{8.3} \mathrm{TCID}_{50} \mathrm{ml}^{-1}$ directly in the branchial vein, and placed in an 80 l aquarium.

Group 2: Thirteen scallops were challenged by exposure to 251 IPNV-contaminated seawater containing $10^{5.7} \mathrm{TCID}_{50} \mathrm{ml}^{-1}$ in an $80 \mathrm{l}$ aquarium. After $3 \mathrm{~h}, 25 \mathrm{l}$ of non-contaminated seawater was added. A slow flow (1 $1 \mathrm{~min}^{-1}$ ) was started after $6 \mathrm{~h}$, and a faster flow (3 $1 \mathrm{~min}^{-1}$ ) started after $12 \mathrm{~h}$.

One day after challenge, the scallops were flushed with seawater, brushed clean and transferred to other aquaria. The aquaria were emptied and flushed on Days 5, $9 \& 12$. Sedimented particles containing faeces and pseudofaeces were collected daily with a siphon from the bottom of the aquaria. The sediment was placed in bottles, decanted, transferred to $50 \mathrm{ml}$ plastic tubes and centrifuged at $4000 \times \mathrm{g}$ for $10 \mathrm{~min}$ at $10^{\circ} \mathrm{C}$. Pellets were resuspended in EMEM, weighed, filtered through $0.2 \mu \mathrm{m}$ disc filters and further diluted in EMEM. Virus isolations and titrations were done as described above. Two weeks after challenge, the surviving scallops of both treatments were sacrificed. Hemolymph was withdrawn with a syringe from the branchial vein, pooled and filtered through $0.2 \mu \mathrm{m}$ disc filters. Tissue samples of approximately equal size were taken from the hepatopancreas and rectum of each scallop, pooled, diluted in EMEM, pounded in a Stomacher Lab-Blender 80 and filtered through $0.2 \mu \mathrm{m}$ disc filters. Virus isolations and titrations were done as described above

Expt 2: Challenge of prawns with IPNV-contaminated feeds. The test animals were 120 deep-water prawn Pandalus borealis with an average length of approximately $45 \mathrm{~mm}$, held in three $250 \mathrm{l}$ aquaria with running filtered seawater at $10^{\circ} \mathrm{C}$.

Group 1: Each of 10 scallops with an average size of $10 \mathrm{~cm}$ received an injection of $1.5 \mathrm{ml}$ of an IPNV suspension with a titer of $10^{6.8} \mathrm{TCID}_{50} \mathrm{ml}^{-1}$ in the branchial vein. The scallops were placed in 2 perforated boxes hung from the surface of the aquarium. This system allowed faeces and pseudofaeces to sediment to the bottom of the aquarium. After $24 \mathrm{~h}$, the 40 prawns were placed in the aquarium. The prawns were not fed during the experiment.

Group 2: The scallops in the boxes in Aquarium 1 were sacrified one by one from Day 2 to 14 and placed on the bottom of Aquarium 2 as food for the 40 prawns. The last scallop was removed on Day 18. One piece of the digestive gland of each scallop was dissected out and treated for virus titrations.

Group 3: The 40 prawns in Aquarium 3 (controls) were fed non-contaminated scallops.

Samples were taken on Days 3, 5, 8, 11, $15 \& 19$, each as a pool from 5 prawns, and on Days 26, 38 \& 54, each as a pool from 3 prawns. Total visceral masses, including intestines, were pooled, diluted in EMEM, disrupted, filtered and assayed for virus.

Expt 3: Challenge of trout with IPNV-contaminated feeds. Six groups of 8 trout each were used. After challenges, trout in all groups were starved for $8 \mathrm{~d}$ and sacrificed. Samples for virus isolation and titration were 
taken from the kidney and spleen of each fish and treated as described above.

Group 1: Eight trout were sacrificed as controls.

Group 2: Eight trout were fed IPNV-contaminated prawns Palaemon elegans as follows: 10 scallops with an average shell height of $9 \mathrm{~cm}$ were each injected with $1.5 \mathrm{ml}$ of an IPNV suspension with a titer of $10^{72} \mathrm{TCID}_{50} \mathrm{ml}^{-1}$ in the branchial vein and placed in an 801 aquarium with running seawater at $10^{\circ} \mathrm{C}$. A group of 260 prawns, with an average length of approximately $22 \mathrm{~mm}$, were fed daily with 1 IPNV-contaminated scallop. The 8 trout were fed twice a day with live contaminated prawns for $14 \mathrm{~d}$. Non-contaminated prawns, contaminated scallop hepatopancreas, contaminated prawn viscera and whole prawns were assayed for virus on Day 4.

Group 3: Eight trout were fed pieces of IPNV-contaminated prawns Pandalus borealis as follows: 6 scallops were injected with IPNV and used to feed $40 P$. borealis over an $8 \mathrm{~d}$ period. The trout were kept in a $250 \mathrm{l}$ aquarium and fed pieces of 30 contaminated prawns over a $14 \mathrm{~d}$ period. Scallop hepatopancreas and whole prawns were assayed for virus as described above

Group 4: Eight trout were fed pieces of non-contaminated prawns (which were fed non-contaminated scallops) as a control to Group 3.

Group 5: Eight trout were fed IPNV-contaminated food pellets as follows: commercial $2.5 \mathrm{~mm}$ dry-pellet fish feed (Skretting Elite plus) was soaked for $1 \mathrm{~min}$ in an IPNV suspension. This resulted in a virus titer of $10^{6.0} \mathrm{TCID}_{50} \mathrm{~g}^{-1}$ pellet wet weight. The trout were fed a total of $7.7 \mathrm{~g}$ of contaminated pellets daily for $14 \mathrm{~d}$. In addition to the virus assay, pieces of pyloric ceca were fixed in buffered $4 \%$ formalin, embedded in paraffin, sectioned, stained with hematoxylin-erythrosin-saffron and examined for histopathology by light microscopy.

Group 6: Eight trout were each injected intraperitoneally with $250 \mu \mathrm{l}$ of IPNV suspension containing $10^{6.6}$ TCID $_{50} \mathrm{ml}^{-1}$.

\section{RESULTS}

Expt 1: Challenge of scallops with IPNV. Group 1: Virus was recovered from all samples of sedimented material from the aquarium holding the injected scallops. Titers of $10^{3.0}, 10^{3.7}$ and $10^{3.4}$ TCID $_{50} \mathrm{~g}^{-1}$ were found on Days 3, 4 \& 11 respectively. The other samples contained amounts of virus below the countable level by end-point dilution (lower than approximately $10^{2.5} \mathrm{TCID}_{50} \mathrm{~g}^{-1}$ ). At the end of the experiment (Day 14), the titer of the pooled sample from rectum was $10^{4.0} \mathrm{TCID}_{50} \mathrm{~g}^{-1}$ and from hepatopancreas

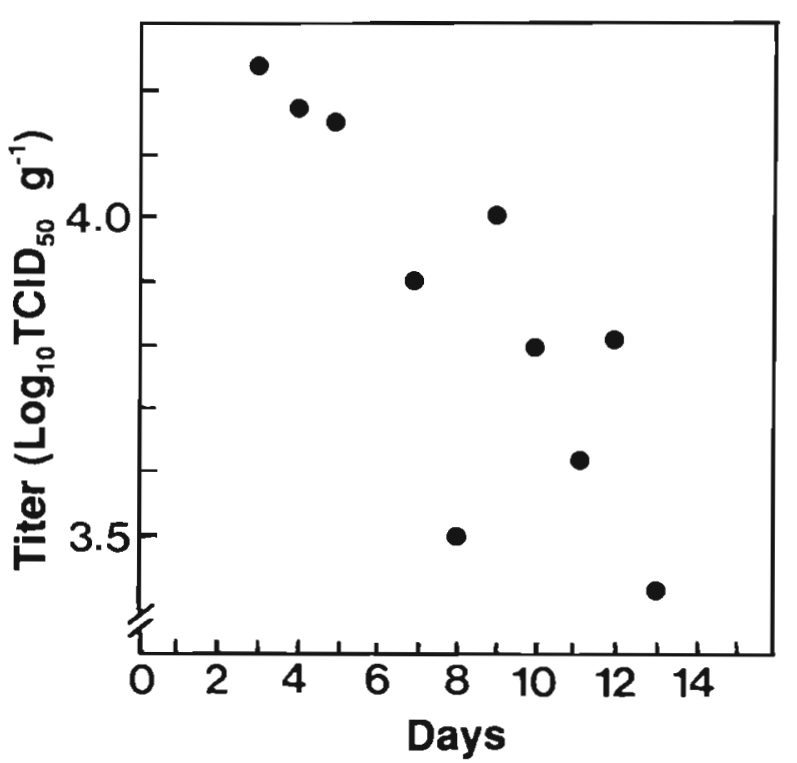

Fig. 1. Virus titers $\left(\log _{10} \mathrm{TCID}_{50} \mathrm{~g}^{-1}\right.$ wet weight) of pelleted faeces/pseudofaeces from scallops Pecten maximus following their exposure to infectious pancreatic necrosis virus (IPNV) in water

$10^{5.8} \mathrm{TCID}_{50} \mathrm{~g}^{-1}$. Virus was also recovered from the hemolymph.

Group 2: Virus was recovered from all samples of sedimented material from the bath-challenged scallops. Virus titers decreased from $10^{42}$ to $10^{3.4} \mathrm{TCID}_{50} \mathrm{~g}^{-1}$ during the experiment (Fig. 1). At the end of the experiment (Day 14) the virus titer of the pooled hepatopancreas sample was $10^{38}$ TCID $_{50} \mathrm{~g}^{-1}$. Virus was recovered from the rectum, but was not detected in the hemolymph.

Expt 2: Challenge of prawns with IPNV-contaminated feeds. Group 1: Virus was recovered from viscera of prawns in the aquarium containing the boxes with IPNV-contaminated scallops, until Day 8 (Table 1). Virus was not detected after Day 8.

Group 2: Virus was recovered from viscera of prawns which had grazed upon the contaminated scallops, until Day 26 (8 d after the last scallop was removed) (Table 1). Virus was not detected after Day 26.

Group 3: Virus was not detected in any control prawns.

Virus titers of hepatopancreas from virus-injected scallops ranged between $10^{4.6}$ and $10^{6.0} \mathrm{TCID}_{50} \mathrm{~g}^{-1}$.

Expt 3: Challenge of trout with IPNV-contaminated feeds. Group 1: Virus was not detected in control trout.

Group 2: Virus was not detected in trout which were fed IPNV-contaminated Palaemon elegans. The virus titers in the prawns were $10^{3.2} \mathrm{TCID}_{50} \mathrm{~g}^{-1}$ of total wet weight $\left(10^{3.8} \mathrm{TCID}_{50} \mathrm{~g}^{-1}\right.$ viscera) (Table 2$)$. 
Table 1. Infectious pancreatic necrosis virus (IPNV) titers $\left(\log _{10} \mathrm{TCID}_{50} \mathrm{~g}^{-1}\right.$ wet weight) of viscera from prawns Pandalus borealis fed faeces and pseudofaeces from contaminated scallops (Group 1), or contaminated scallop soft parts (Group 2). + : virus detections below the level of countability by end point dilution (ca $10^{2.5} \mathrm{TCID}_{50} \mathrm{~g}^{-1}$ wet weight); -: samples where virus was not detected

\begin{tabular}{|ccc|}
\hline Day & Group 1 & Group 2 \\
\hline 3 & 2.5 & 2.5 \\
5 & 3.8 & 4.1 \\
8 & 3.8 & 3.9 \\
11 & - & 3.2 \\
15 & - & 4.1 \\
19 & - & 4.0 \\
26 & - & + \\
38 & - & - \\
53 & - & - \\
\hline
\end{tabular}

Group 3: Virus was not detected in trout which were fed pieces of IPNV-contaminated Pandalus borealis. The virus titer in the prawns was approximately $10^{2.5} \mathrm{TCID}_{50} \mathrm{~g}^{-1}$ of total wet weight.

Group 4: Virus was not detected in trout which were fed pieces of non-contaminated Pandalus borealis.

Group 5: Virus was detected in kidneys and spleens of 2 trout which were fed contaminated pellets (with a titer of $10^{6} \mathrm{TCID}_{50} \mathrm{~g}^{-1}$ ) (Table 2). In both fish, inflammation and moderate focal necrosis were observed in pancreatic tissues. Pancreatic tissues appeared normal in the other 6 trout.

Table 2. Infectious pancreatic necrosis virus (IPNV) titers $\left(\log _{10} \mathrm{TCID}_{50} \mathrm{~g}^{-1}\right.$ wet weight) of contaminated feeds, and of kidneys and spleens of challenged brown trout Salmo trutta. -: samples where virus was not detected

\begin{tabular}{|lcccc|}
\hline \multicolumn{1}{c}{ Group } & Feed & Fish no. & Kidney & Spleen \\
\hline 1. Nontreated controls & - & $1-8$ & - & - \\
2. Fed contaminated & 3.2 & $1-8$ & - & - \\
$\quad$ Palaemon elegans & & & & \\
3. Fed contaminated & 2.5 & $1-8$ & - & - \\
$\quad$ Pandalus borealis & & & & \\
4. Fed non-contaminated & - & $1-8$ & - & - \\
$\quad$ P. borealis & & & & \\
5. Fed contaminated & 6.0 & 1 & 4.2 & 3.8 \\
pellets & & 2 & 5.1 & 4.5 \\
& & $3-8$ & - & - \\
6. Injected with & & & & \\
250 41 IPNV suspen- & & 1 & 5.9 & 3.9 \\
sion (106 ${ }^{6}$ TCID $\left._{50} \mathrm{ml}^{-1}\right)$ & & 2 & 4.9 & 3.2 \\
& & 3 & 4.6 & 4.0 \\
& & 4 & 4.0 & 3.2 \\
& & 5 & 6.4 & 6.5 \\
& & 6 & 4.5 & 4.7 \\
& & 8 & 5.2 & 4.5 \\
& & & 4.9 & 4.9 \\
\hline
\end{tabular}

Group 6: Virus was detected in kidney and spleen samples from all 8 trout injected with an IPNV suspension (Table 2).

\section{DISCUSSION}

As reviewed by Beninger (1991), food containing mucus cords, including various trapped material, is partly expelled as pseudofaeces in scallops. Accordingly, not all the sedimented material collected in Expt 1 would have passed through the alimentary tract of the scallops. The finding of virus in the rectum of the scallops is in accordance with our previous results with IPNV bath-challenged scallops (Mortensen et al. 1992). Our results thus indicate that infectious IPNV is passed through the alimentary tract and is present in the faeces of contaminated scallops.

Virus injected into the branchial vein of scallops also passed through the alimentary tract, and was recovered from particles in the tank. These results are also in accordance with our previous findings. The lower titers in the faeces samples, isolation of virus from the hemolymph by the end of the experiment, and the relatively high titers in hepatopancreas and rectum indicate a gradual depuration of virus. Transportation of soluble, biotic and abiotic material by hemocyte diapedesis has been shown in bivalve molluscs (Stauber 1950, Tripp 1960, Feng 1965), and the present results suggest that injected virus was cleared by transportation from the hemolymph, released into the digestive tract and excreted via faeces.

A slow release of IPNV has been shown to occur from freshwater crayfish (Halder \& Ahne 1988) as well as from carrier salmonid fish (Billi \& Wolf 1969) Depuration of foreign particles from bivalve molluscs is known to be relatively slow. The present finding of IPNV in the rectum and in tank sediment, as well as the long persistence time of IPNV in the scallops (Mortensen et al. 1992), indicates that a slow release of IPNV-containing faeces particles might occur from contaminated bivalve molluscs.

Studies by Rice et al. (1980) suggested that Pandalus species are food generalists who ingest large amounts of detritus and sediment in addition to traditional invertebrate prey. Although the prawns might have been exposed to virus from the water, it seems likely that the prawns kept in the tank containing the baskets with scallops became contaminated by grazing upon sedimenting particles. However, virus concentration decreased to below titratable levels when the contaminated scallops were removed from the baskets, indicating that virus was being rapidly depurated after the contaminated food source was removed.

McAllister \& Owens (1986) showed that mortality of 
brook trout juveniles challenged with IPNV by immersion was correlated to virus concentration, exposure time and the age of the fish. The failure to transmit IPNV to the trout by feeding with contaminated prawns could also be due to such factors. The $8 \mathrm{~d}$ incubation time employed should, however, have been long enough to induce infection (Swanson \& Gillespie 1979, Swanson et al. 1982). Intraperitoneal injections of IPNV in trout resulted in infection of the kidney and spleen. This is confirmed by histopathological study of affected pancreas tissues, and also demonstrates the virulence of the virus used. Experimental oral transmission of IPNV has previously been shown to establish infections in Atlantic salmon Salmo salar (Swanson \& Gillespie 1979) and turbot Scophthalmus maximus (Castric et al. 1987). When Swanson \& Gillespie (1979) fed Atlantic salmon juveniles an IPNV-contaminated diet for $1 \mathrm{~d}$, the virus was not reisolated from all specimens. The present results are consistent with theirs, although trout in the present study were fed for $14 \mathrm{~d}$, a period of time long enough to allow each specimen to ingest a relatively large amount of contaminated feed. Swanson \& Gillespie (1979) also showed that feeding resulted in measurable virus titers in the water. Thus, a waterborne challenge might also have occurred in the present study.

In conclusion, the results demonstrate that IPNV is excreted via faeces of contaminated bivalve molluscs. The virus may be transmitted to prawns after feeding on dead bivalves or on faeces and pseudofaeces. Under the present experimental conditions, a further transmission from prawns to trout was not achieved. The observed results might indicate that the contaminated prawns did not represent a challenge dose sufficient to cause infection in the trout. Considering the numerous factors influencing both virulence of the agent and susceptibility of the fish, a transmission of virus to fish feeding on contaminated invertebrates must however still be considered as a realistic possibility.

Acknowledgements. Thanks to Lisbeth Harkestad, Ingrid Uglenes and Hari Rudra for excellent technical assistance and Johan Glette, Øystein Evensen and Brit Hjeltnes for their advice and constructive criticism. Special thanks to Malcolm Hurtley and Sissel Andersen for providing the scallops, and to Tor J. Samuelsen at Bergen Aquarium who organized the trawling. This work was supported by the Norwegian Fishery Research Council. Partial support was received from the Norwegian Regional Development Fund and a/s MOWr.

\section{LITERATURE CITED}

Beninger, P. G. (1991). Structures and mechanisms of feeding in scallops: paradigms and paradoxes. In: Shumway, S. A.,

Responsible Subject Editor: F. M. Hetrick, College Park, Maryland, USA
Sandifer, P. A. (eds.) An international compendium of scallop biology and culture. World Aquaculture Workshops No. 1, World Aquac. Soc., Baton Rouge, LA, p. 331-340

Billi, J. L., Wolf, K. (1969). Quantitative comparison of peritoneal washes and feces for detecting infectious pancreatic necrosis (IPN) virus in carrier brook trout. J. Fish. Res. Bd Can. 26: $1459-1465$

Canzonier, W. J. (1971). Accumulation and elimination of coliphage S-13 by the hard clam Mercenaria mercenaria. Appl. Microbiol. 21: 1024-1031

Castric, J., Baudin-Laurencin, F., Coustans, M. F., Auffret, M. (1987). Isolation of infectious pancreatic necrosis virus, Ab serotype, from an epizootic in farmed turbot, Scophthalmus maximus. Aquaculture 67: 117-126

Christie, K. E., Ness, S., Djupvik, H. O. (1990). Infectious pancreatic necrosis virus in Norway: partial serotyping by monoclonal antibodies. J. Fish Dis. 13: 323-327

Di Girolamo, R., Liston, J., Matches, J. (1977). Ionic bonding, the mechanism of viral uptake by shellfish mucus. Appl. environ. Microbiol. 33: 19-25

Feng, S. Y. (1965). Pinocytosis of proteins by oyster leucocytes. Biol. Bull. 128: 95-105

Halder, M., Ahne, W. (1988). Freshwater crayfish - a vector for infectious pancreatic necrosis virus (IPNV). Dis. aquat. Org. 4: 205-209

Hay, B., Scotti, P. (1986). Evidence for intracellular adsorption of virus by the pacific oyster, Crassostrea gigas. N.Z. J mar. Freshwat. Res. 20: 655-659

McAllister, P. E., Owens, W. J. (1986). Infectious pancreatic necrosis virus: protocol for a standard challenge to brook trout. Trans. Am. Fish. Soc. 115: 466-470

Mortensen, S. H., Bachere, E., LeGall, G., Mialhe, E. (1992). Persistence of infectious pancreatic necrosis virus (IPNV) in scallops Pecten maximus. Dis. aquat. Org. 12: 221-227

Mortensen, S. H., Hjeltnes, B., Rødseth, O., Krogsrud, J., Christie, K. E. (1990). Infectious pancreatic necrosis virus, serotype N1 isolated from Norwegian turbot (Scophthalmus maximus), halibut (Hippoglossus hippoglossus) and scallops (Pecten maximus). Bull. Eur. Ass. Fish Pathol. 10(2): $42-43$

Okamoto, N., Shirakura, T., Nagakura, Y., Sano, T (1983). The mechanism of interference with fish viral infection in the RTG-2 cell line. Fish Pathol. 18: 7-12

Reed, L. J., Muench, H. (1938). A simple method of estimating fifty percent end points. Am. J. Hyg. 27: 493-497

Rice, R. L., McCumby, K. I., Feder, H. M. (1980). Food of Pandalus borealis, Pandalus hypsinotus and Pandalus goniurus (Pandalidae, Decapoda) from lower Cook Inlet, Alaska. Proc. natl Shellfish Ass. 70: 47-54

Stauber, L. A. (1950). The fate of india ink injected intracardially into the oyster, Ostrea virginica Gmelin. Biol. Bull. 98: $227-241$

Swanson, R. N., Carlisle, J. C., Gillespie, J. H. (1982). Pathogenesis of infectious pancreatic necrosis virus infection in brook trout, Salvelinus fontinalis (Mitchill), following intraperitoneal injection. J. Fish Dis. 5: 449-460

Swanson, R. N., Gillespie, J. H. (1979). Pathogenesis of infectious pancreatic necrosis in Atlantic salmon (Salmo salar). J. Fish. Res. Bd Can. 36: 587-591

Tripp, M. R. (1960). Mechanisms of removal of injected microorganisms from the American oyster, Crassostrea virginica (Gmelin). Biol. Bull. 119: 210-223

Wolf, K., Quimby, M. C. (1962). Established eurythermic line of fish cells in vitro. Science 135: 1065-1066

Manuscript first received: October 9, 1992

Revised version accepted: April 11, 1993 